\title{
Issues of Power and Empowerment in Refugee Studies: Rwandan Women's Adaptive Behaviour at Benaco Refugee Camp
}

\author{
Judy A. Benjamin
}

\begin{abstract}
This paper addresses human rights violations in the context of gender power relationships and calls attention to the need to examine the standards for human rights assessments in the context of refugee situations. This research is based on fieldwork carried out with Rwandan Hutu refugees during an 18-month assignment as Project Director for CARE International in Ngara, Tanzania. Participant observations, interviews, surveys, and focus group discussions yielded a wealth of data concerning the coping strategies of men and women. Women's coping strategies made them vulnerable: women without partners were the least protected and took the greatest risks in their efforts to survive and feed their children. Their adaptive behaviour increased their risks of rape, sexual abuse, and exposure to HIV and other sexually transmitted diseases. These serious problems were overshadowed by the chaotic business of running a refugee camp. In the rush to accommodate the influx of hundreds of thousands of refugees, the non-governmental organizations and UN agencies established a relief infrastructure that-perversely-gave the perpetrators of crimes, positions of power within the camp, which enabled the gender violations to persist.
\end{abstract}

\section{Précis}

Le présent article aborde la question de la violation des droits humains dans le contexte des relations de pouvoir dans le sexage etattirel'attention sur la nécessité d'un examen des critères d'évaluation des droits humains dans un contexte où la question des réfugiés est impliquée. Cette recherche est basée sur un travail de ter-

Judy A. Benjamin is Technical Advisor for the Women's Commission for Refugee Women and Children, New York, NY, USA. rain mené auprès de réfugiés Outous rwandais lors d'une affectation de 18 mois comme Directeur de Projet pour CARE International à Ngara en Tanzanie. L'observation de participants, les entreoues, les enquêtes, les discussion des groupes de travail ont fourni une masse de données sur les stratégies de survie émotive des hommes et des femmes. Les stratégies de survie émotive des femmes les rendent particulièrement vulnérables. Ainsilesfemmes sans conjoints sont les plus vulnérables et prennent les plus grand risques dans leur effort pourassurer leur survie et nourrir leurs enfants. Leur pratiques d'adaptation les exposent à un risque accrude viols, d'abus sexuels, et d'expositions au HIV et autres virus transmis sexuellement. Ces problemes graves sont totalement éclipsés par l'activité chaotique de gestion d'un camp de réfugié, par l'urgence de rencontrer les besoins de l'afflux de centaines de milliers de réfugiés. Dans ce contexte, les organisations non-gouvernementales et les agences des Nations Unies ont établi une infrastructure d'assistance qui, de façon fort perverse, a donné aux auteurs de ces crimes accèsà des positions de pouvoir dans le camps de réfugiés qui ont permis aux exactions à caractère sexuel de se perpétuer.

The tattered curtain covering the entrance to my blinde does not stop them. They come in thenight, have their way with me and leave. I am afraid but there is no one to help me. (Bernadette, unmarried mother, age 19).

My children eat cooked food every otherday - there isn'tenough firewood, the maize grain takes so many hours to cook. My husband is dead. I am alone. I am afraid to go out alone to collect wood. (Zameda, mother of 5, age 30 )
My parents arranged my marriage to Charles against my will. $\mathrm{He}$ is old and drinks too much. (Charlotte, age 14 , one of 10 children)

I heard the child screaming in the night. We learned in the morning that she had been raped in the latrine by a boy of 20-he had been drinking. (Neighbour of Felicitee, age 6)

I am forced to give half of my food rations to a neighbour-he is protecting me. (Natalie, widow, mother of 4)

\section{Introduction}

The voices of Natalie, Charlotte, Zameda, and Bernadette echo those of many other refugees who endured abuses in Benaco refugee camp, Tanzania, because they were women. Being a refugee in Benaco meant braving daily hardships and indignities, and women suffered even more than men did. This article aims to provide a theoretical framework for studying the relationship between violence against women refugees and human rights violations that occur when communities are displaced. In particular, the results of women's survival strategies and the level of riskinvolved in their coping behaviour are examined.

\section{Theoretical Basis of the Study}

This workdraws from theories on social change, refugee studies and gender violence. The Rwandan genocideprovides a tentative theoretical framework for examining violence in refugee camps, including rapes and sexual violence against women and girls. The idea is put forth that human rights violations, particularly rape, can best be identified through the use of small focus group discussions. The notion of categorizing 
women refugees as "vulnerables" is contested in this paper. Women are not passive victims but are put into vulnerable situations especially during periods of conflict and social upheaval, including internal displacement and refugeemobility.

\section{The Rwandan Conflict and the Flight to Tanzania}

On April6, 1994, the plane carrying the presidents of Rwanda and Burundi mysteriously crashed. Murderous rampages by Hutu extremists driven to carry out the carefully-planned elimination of Rwandan Tutsis began immediately. (For a comprehensive history of the genocide see Prunier 1995.) The genocidal slaughtering continued for more than two months until the rebel Tutsi army (Rwandan Patriotic Front) succeededingaining control of the country. Within a few days, and in the largest single movement of people in so short a time, more than half a million Hutus fled Rwanda to neighbouring countries, fearing retribution from Tutsi soldiers for the killings. Entire communities of Hutus left Rwanda. The genocide leaders convinced Hutus who had not been involved in the slaughter to leave by telling them that the Tutsis would kill all Hutus. The degree of control that the militant factions had over other Hutus proved to be a crucial element in the Rwandan refugee story, although relief workers were not aware of the degree of control untillate in the situation (Prunier 1995).

The Benaco refugee camp, located just 18 kilometres from the Rwandan border, became the second largest "town" in Tanzania. The United Nations, along with nearly 20 international non-governmental organizations (NGOs), quickly set up relief operations.

In December 1996, the refugees abandoned Benaco and returned to Rwanda.

\section{Refugee Camp Organization}

Human rights violations at Benaco must be viewed within the context of the genocide that occurred in Rwanda. Credible observers noted numerous human rights violations against women, although the enormity and scope of the mass murders appeared to eclipse this issue. Most rights violations against women and girls failed to draw any response from the NGOs and relief agencies. Beset by a myriad of problems-outbreaks of cholera, measles, meningitis, and ongoing security incidents-many relief workers minimized the importance of women's complaints or completely ignored them.

Refugee literature has often depicted women as powerless victims (Stein 1981). Portraying refugee women in passive dependent roles does not accurately describe the majority of refugee women (Daley 1991). In the camps, women were mainly responsible for continuing the social activities of the household, which included caring for the sick, children, and elderly family members. Along with endless daily chores-securing firewood, water, and food preparation-they also bore the physical responsibilities of pregnancy and lactation. Life in the camps entailed far more pain and suffering for women than for men. Rather than pointing to weakness, dependency, and vulnerability, the adaptability of refugee women to adverse circumstances shows their strength to do what was necessary to survive their ordeal.

The situational context of the Hutu refugees, cast in the shadow of genocide, often caused people to behave in uncharacteristic and unpredictable manners. This article focuses on the risk-taking behaviours that are the coping mechanisms of survival for refugee women. I argue that women-especially single women-are in greater danger than men because of gender power relationships that arise or are reinforced when communities are displaced. It is their tenacity and will to survive-not their vulnerability - that cause them to adopt behaviours that jeopardize their human rights, health, and social status. In Benaco, the most common rights violations encountered in this Faustian bargain to survive included rape, coercive sex (exchanging sex for food, water, firewood or protection), discrimination, social ostracizing, and financial exploitation. Coping strategies which included trading sex for needed goods or services often increased the risk of exposure to HIV and other sexually transmitted diseases (STDs), especially given the high prevalence of these diseases in the Rwandan population (van der Straten et al. 1995).

\section{Women and Girls at Risk}

Life for refugee women and girls is harsh. Many women on both sides of the conflict were beaten and raped during their exodus. For Rwandan women, social status and identity are closely linked to marriage and family. One of the biggest threats to the physical safety of women and girl refugees is the lack of employment for men. This leads toboredom, depression and an increase in alcohol consumption-which in turn lead to increased domestic violence and rape. Unfortunately, few rapes were ever reported to the authorities, partly because Tanzanian law makes prosecution for rape nearly impossible.

Women without male protectors (husbands, fathers, uncles) were particularly vulnerable in the camps. Many women who were raped during the conflict gave birth tobabies. These so-called "unmarriedmothers" were easy targets, with no one to stand up for them. They reported that men walked into their huts at will, raped them and left. Because they occupied such a low rung on the social ladder, they received little sympathy from the community. The AIDS prevention project helped start support groups for these women, who found strength by uniting with others suffering the same fate. They also benefited from special income-generation efforts, such as produce-growing cooperatives set up by other NGOs within the camps.

When the camps were new, large communallatrines were built some distance from the dwellings. These structures, sheltered by large sheets of plastic, became the site of many sexual assaults on women and girls. The situation improved after small four-family latrines were builtnearer homes, replacing most of the communal ones. Women and children seeking firewood outside camp boundaries were also victims of assault. 
In response to thenumber of assaults, a crisis intervention team was formed made up of refugee social workers, counsellors and other volunteers who provided counselling, medical and legal assistance, and social support for victims of sexual assault.

Even women who were not victims of violence and sexual assault were often powerless to insist on safer sex practices. Because condom use is often associated with promiscuity, women were afraid to suggest condoms to their partners.

\section{Coping Strategies and Risk}

The conditions of refugee life greatly increase the risk of exposure to HIV and otherSTDs. The destruction of families, deterioration of social structures and unravelling of social mores, loss of homes and income, overburdened health care resources, crowding, and commercial sex trade within refugee camps are just some of the factors that lead to increased risk-taking behaviour and susceptibility. Women and adolescent refugees, vulnerable to violence, rape and coercive sex, are at especially high risk.

Lack of social support networks for many refugees may mean facing all problems alone without any support. Responses on a survey carried out in the camp regarding attitudes on social support indicated that women without partners felt socially isolated, with no one to turn to for advice on personal matters. Many women at Benaco were either widowed or had been separated from theirfamilies. Several of the women interviewed attributed their tendencies to attach themselves to men they hardly knew to their fear and loneliness.

Social network analyses suggested the formation of new social relations based on need fulfilment. Groups of young men set up shared households to maximize resources. Many of these "bachelor blindes" were where young girls were raped. Parents complained bitterly that they no longer had control over their older children. The most frequent expression of this was the case of adolescent girls. The absence of schools beyond primary level meant boredom and idleness for large numbers of refugee teenagers. Boys were able to establish some small income-generating activities such as collecting and selling firewood, taxiing people on the backs of bicycles, etc. No such outlets existed for adolescent girls. Adolescent girls who participated in focus groups revealed their feelings of anxiety and fear. They expressed feelings of hopelessness and distress overnothaving access to money and not having activities, and especially missed being in school. Many young girls formed relationships with oldermen whogave themmoney orgifts. Some of these fast-formed relationships resulted in the girls being physically abused.

Knowledge, Attitude, Beliefs and Behaviour(KABB) baseline and follow-up surveys showed that the percentage of women who had multiple sexual partners rose from 14 percent to 38 percent during the first 12 months. These data suggest that one of the coping strategies of women included an increase in the number of sexual partners, although one should be careful not to infer too much from this finding. The rise in the percentage of women with multiple sexual partners could be attributed to increased willingness to answer personal questions.

\section{Findings and Analyses}

In addition to the AIDS/STD prevention intervention activities, the project focused on how the coping strategies of refugees often resulted in behaviour likely to increase the transmission risks of HIV and other sexually transmitted diseases. Short-term coping strategies employed by women often entailed long-term negative consequences. Women may choose to live with a man in exchange for protection or food rations. They increase their health risks when they are forced to trade sex for food, water, money or protection, increasing their chances of exposure to STDs, including HIV. According to the UNSpecial Rapporteur on the Commission on Human Rights in Rwanda, "100 cases of rape gave rise to one pregnancy" (Human Rights Watch 1996, 24). The number of pregnancies result- ing from rapes in Rwanda following the genocide was estimated to be between 2,000 and 5,000. Shame often prevented women from seeking treatment when symptoms of STDs appeared. Untreated cases resulted in painful pelvic infections that could result in permanent sterility. Shame also keptrape victims from reporting the crime. Refugee women and girls experience more abuses and human rights violations because of their coping strategies, whereas men's ways of adapting to life in the camps did not expose them to such risks.

Abusive behaviour was at times excused as "cultural practices" with the rationalization that such behaviour is part of the culture. Westerners are reluctant to interfere when the word "cultural" is bantered about. Cultural taboos against women speaking out, fear of not being believed, and shame prevented many women and girls from reporting human rights abuses.

\section{Discovering Human Rights Abuses in the Course of a Refugee AIDS Prevention Program}

Rwanda has been hit hard by the AIDS epidemic. In some sectors of the population infection rates have been among the highest in Africa. In 1992, for example, testing of pregnant women attending antenatal clinics in Kigali, Rwanda's capital, revealed that more than 30 percent were HIV seropositive (Allen 1992). One could reasonably expect that infection rates among refugees were at least as high as they had been in Rwanda, although HIV testing was not widely available in the camps. The need for an AIDS education and prevention program for Rwandan refugees was well supported.

The task of implementing an AIDS prevention program for positive behaviour change proved daunting in a climate of resistance and contested power relationships. The research efforts of the project sought to provide relevant and reliable data with which to design targeted approaches for implementing the AIDS prevention program. Furthermore, the research tried to find underlying explanations for certain behaviours. 
Because AIDS research delves into the sexual lives of individuals, AIDS research and research on human rights violations share the very sensitive common ground of examining subjects' intimate behaviours. Unlike other research that lends itself to quantitative methods, research on sexual behaviour normally is constrained to relying on information gathered in qualitative (and more circumspect) ways. In the course of examining women's personal lives we inadvertently found ourselves examining sexual and human rights abuses, which emerged as an inseparable issue. The project provided an invaluable service by establishing safe havens and a climate in which women felt comfortable talking about their problems. Many of the abuses we learned about would never have been discovered had it not been for the project's sensitively reaching out to women and providing a safe place where these topics could be discussed. In particular, the method of small focus group discussions gave women the courage and opportunity to share traumatic experiences that they had never discussed openly. In the baseline Knowledge, Attitude, Beliefs and Behaviours survey (KABB 1994), nearly 70 percent of women surveyed felt they had no one they could turn to for personal advice. One year later, only 38 percent felt such social isolation.

\section{Lessons Learned}

This pilot AIDSproject was the first of its kind in a large refugee population. We learned that forming small, non-threatening groups and knowing what questions to ask was the way to get women to feel more comfortable talking about rape, coercive sex, and other abusive behaviour. The technique of probing with questions (e.g., do you know any women who have been raped?), rather than asking outright what had happened to them personally, allowed women to respond anonymously. The small groups of six to eight women facilitated discussions of taboo subjects without endangering the participants. Often, spontaneous personal revelations would follow once women felt safe enough to tell their own painful experiences.

The first step towards getting the community to confront the problem of sexual violence was to acknowledge that a problem existed in the first place. At the onset of the project, it appeared that refugees accepted the sexual violence as an inevitable part of life within the camps. Focus groups with men in various sectors of the community were held to learn their views. When the issue was personalized in these groups, relating the abuses to "your wife, daughter, etc.," the community admitted that sexual violence was indeed a real problem and could be handled by the community itself. Such an admission proved to be the first step in community "ownership" of the problem of sexual violence, and practical solutions such as setting up group wood collections, neighbourhood watches, safe areas, etc. began to be discussed. Most importantly, the community unveiled the shroud of secrecy around rape and violence and began to discuss solutions.

Many researchers believe that qualitative data donot command the respect of hard quantitative data. However, as this study shows, qualitative data were likely to yield the richer and more reliable account. Moreover, in sensitive situations such as those surrounding rights violations within the camps, qualitative methods revealed information that would not be found in a standardized questionnaire or survey method. This advantage came not from any inherent advantage of qualitative methods but rather because the situation within the Benaco camp made quantitative methods so susceptible to manipulation that they actively hid certain truths and blatantly distorted others.

\section{Difficulties of Undertaking Research in Refugee Camps}

Authors have addressed problems experienced by researchers working with populations of refugees who have.suffered unspeakable hardships (Allen 1996; Omidian 1994). Less attention has been paid to the difficulties faced by anthropologists working with refugees accused of violent crimes. Conducting research among a population harbouring known murderers proved incredibly difficult and stressful. Relief workers often lacked conviction helping people who had participated in genocide, and the aid recipients were often suspicious of the efforts made to help them. Such considerations forced researchers and relief workers to make unexpected and uncommon revisions to their field methods (Krulfeld 1994).

The subjects of trust and honesty between those studied and the researcher need to be examined when conducting anthropological research among refugees. Voutira and Harrell-Bond (1995, 209) explore the "locus of trust" in refugee situations. In the Rwandan situation, suspicion of the others' underlying motives characterized many of the encounters between relief workers, refugees and researchers. After a while, some researchers began to question the validity of their own data, gathered as they were from encounters rife with mistrust, manipulation, and, sometimes, outright deceit. However, small focus group discussions circumvented this persistent aura of falsehood and constructed responses and gave many valuable and truthful insights about the daily coping strategies of refugees.

The researcher's motivation and honesty may be called into question. Researchers may exploit refugees by subjecting them to endless questionnaires, surveys, and interviews. In most cases, refugees never have the opportunity to learn the results of research or are often not told why the research is being done. This behaviour is abusive and violates the rights of refugees. A participatory research approach engaged the refugees by first obtaining consensusfor the need for information, and secondly, enabling refugees to participate in research design, select the method, carry out the research, and analyze the findings.

\section{Recommendations}

Anthropologists working in refugee settings must be ready to expand existing data collection approaches and analytical methods, and explore new ones. 
Fieldwork that combines advocacy with research, recording processes of change while trying to influence positive behaviour changes, casts the researcher as an agent of change. This project showed the possibilities of engaging refugees in activities to promote health-seeking behaviour in spite of the many forces working against adopting such positive behaviour styles. What was underestimated was the effect of the militant extremists' political control and flagrant manipulations in the camps and the brutal consequences on the lives of all refugees-especially women and girls.

Against the backdrop of the genocide and the illicit military buildup and training activities inside the camps, human rights abuses were largely ignored. This research shows that many coping strategies are gender-specific, and suggests the need to examine why men and women responded and adapted differently to life in camps. Relief agencies may use this knowledge to design more effective programs to specifically address theneeds of women refugees.

Agencies can enable women to use their skills by providing the type of assistance that will encourage positive behaviour. By being aware of detrimental coping methods and structural design of camps, relief agencies can provide safer refuge for women. At the earliest possible time, womenneed to be consulted in camp layout design and in the provisioning of community social and health services. Agencies can also set up commodity distributions (food and non-food items) so as to make women the direct beneficiaries. Early monitoring of household livelihood security, along with nutritional surveys that include adolescents, adult women and the under-five population, will provide baselines that can show whether or not women are actually eating the distributed food. Moreover, in order to assure that women refugees have equal access to commodities, women need to be put in decision-making roles in refugee camp management.

In refugee settings where numerous NGOs implement program services, collaboration and partnering will in- crease their contributions to the relief efforts. Information, survey and questionnaire results and training can be pooled and shared to maximize the impact and maintain cultural appropriateness.

The special physical and health needs of women must be taken into account from the beginning of an emergency. These needs include reproductive health services as delineated in the United Nations High Commissioner for Refugees (UNHCR) manual Reproductive Health in Refugee Situations (1995). Providing HIV/STD prevention and family planning commodities is also essential, especially among populations with high HIV seroprevalence and groups accustomed to birth spacing options. Rape crisis intervention is needed from the start of an emergency situation, and health agencies experienced in trauma counselling and treating rape cases are urgently needed. Above all, refugee services must be accessible; e.g., condoms and child spacing information need to be easily available and visible at food distribution sites.

To help women prepare unfamiliar food, cooking instructions should be provided at food distribution locations. During the first few weeks of setting up a refugee camp, firewood or fuel should be provided until such time as relief agencies can ascertain the safest and leastenvironmentally destructive methods for obtaining cooking fuel. Men need tobeorganized into wood-cutting teams to reduce the risks for individual women and girls going far from the camps in search of wood. The Community Services sector should facilitate the formation of support networks for women who are not accustomed to being alone in such conditions. Support networks would be empowering for women and, at the same time, reduce the chances that women wholive alone will have to resort to coping behaviour which puts their health and human rights at risk.

\section{Conclusion}

The relief operation in Tanzania was in response to violence. By not censuring violent behaviouritwas perpetuated in many realms in the camps. That the perpetrators of genocide were allowed to set up shop (including arms storage and military training exercises) just across the border from Rwanda, points to theneed for the international community (the United Nations, donor governments, and NGO relief agencies) to take a united stance against supporting criminal behaviour. John Shattuck $(1996,171)$ wrote:

... it is increasingly clear that humanitarian efforts are doomed to fail unless they are accompanied by political efforts aimed at keeping the peace, establishing accountability, and deterring conflict in the long term. One of the greatest tasks facing the international community today is to create institutional mechanisms to respond to this combined and growing pressure of humanitarian and political human rights crises.

It should not have been a surprise that violent behaviour continued inside the refugee camps, especially by those wielding the power over the unprotected, i.e. unaccompanied women and young girls. People whogo unpunished for serious violent crimes perceive no constraints against further violent behaviour.

Ultimately, if the relief structure purports to care abouthuman rights, it must place human rights as a priority at the onset of the program, not later. The Rwandan crisis defined the now popular term "complex humanitarian emergency." The enormous and swift influx of refugees into Tanzania and Zaire stunned the unprepared relief community. Relief efforts were concerned with alleviating suffering and providing basic needs-water, food, shelter, and medicine. The logistical problems were extraordinary. A quarter of a million peopleneeded to be fed and housed and it seemed prudent at the time to engage the leadership to organize the distribution of rations. The practice of allowing veritable genocidecriminals positions of power in the camps, however, as commune leaders, section heads, food monitors, security guards, sets the stagefor the continuation of violence on another level. 
To be fair, relief agencies had little or no history dealing with genocide: their mandates are simply to relieve suffering and save lives. Whereas the agencies should not be reproached for their performance in such unfamiliar circumstances, fingers should point instead at governments that would not even use the word "genocide" lest they be forced to fulfil their obligation under international law to intervene.

Situations in camps often prevent women from being able to protect themselves. Women are not inherently weak and vulnerable. Rather, situations arise in which women are unable to act in their own bestinterests. It is the responsibility of the relief agencies to ensure that they do not inadvertently place women into such situations. These refugee women are relying on the agencies as a source of sustenance in the life-anddeath circumstances of the camps.

Knowing where to place the blame should not be the lesson learned from Rwanda. Instead, international organizations and states must urgently seek effective strategies and means to avert conditions provoking the wholesale violence witnessed there. And when relief efforts prove necessary, relief organizations must guard against accidentally providing the climate for violence to continue. In the spirit of humanitarian aid, refugee camps should be places of healing.

\section{References}

Allen, Beverly. 1996. Rape Warfare: The Hidden Genocide in Bosnia-Herzegovina and Croatia. Minneapolis: University of Minnesota Press.

Daley,Patricia. 1991. “Gender, Displacement and Social Reproduction." Journal of Refugee Studies 4, no. 3.

Human Rights Watch/Africa. 1996. Shattered Lives: Sexual Violence during the Rwandan Genocide and Its Aftermath. New York: Human Rights Watch.

Krulfeld, Ruth M. 1994. "Methods in Refugee Research.InReconstructing Lives, Recapturing Meaning Refugee Identity, Gender, and Culture Change, edited by Linda A. Camino and Ruth M. Krulfeld, 147-50. Washington, DC: Gordon and Breach.

Omidian, Patricia A. 1994. "Life out of Context: Recording Afghan Refugees' Stories." In Reconstructing Lives, Recapturing Meaning Refugee Identity, Gender, and Culture Change, edited by Linda A. Camino and
Ruth M. Krulfeld, 151-77. Washington, DC:Gordon and Breach.

Prunier, Gerard. 1995. The Rwanda Crisis: History of a Genocide. New York: Columbia University Press.

Shattuck, John. 1996. "Human Rights and Humanitarian Crises: Policy-Making and the Media." In From Massacres to Genocide The Media, Public Policy, and Humanitarian Crises, edited by Robert I. Rotberg and Thomas G. Weiss, 169-75. Cambridge: World Peace Foundation.

United Nations High Commissioner for Refugees(UNHCR). 1991. Guidelines on the Protection of Refugee Women. Geneva:UNHCR, July.

- 1995. Reproductive Health in Refugee Situations: An Inter-Agency Field Manual. Geneva: UNHCR, Program and Technical Support Section.

Van der Straten, Rachel King, Olga Grinstead, Antoine Serufilira, and Susan Allen. 1995. "Couple Communication, Sexual Coercion and HIV Risk Reduction in Kigali, Rwanda." AIDS 1995, 9, 935-944.

Voutira, Eftihia and Barbara E. Harrell-Bond. 1995. "In Search of the Locus of Trust: The Social World of the Refugee Camp." In Mistrusting Refugees, edited E. Valentine Daniel and John Chr. Knudsen, 207-24. Berkeley: University of California Press. .

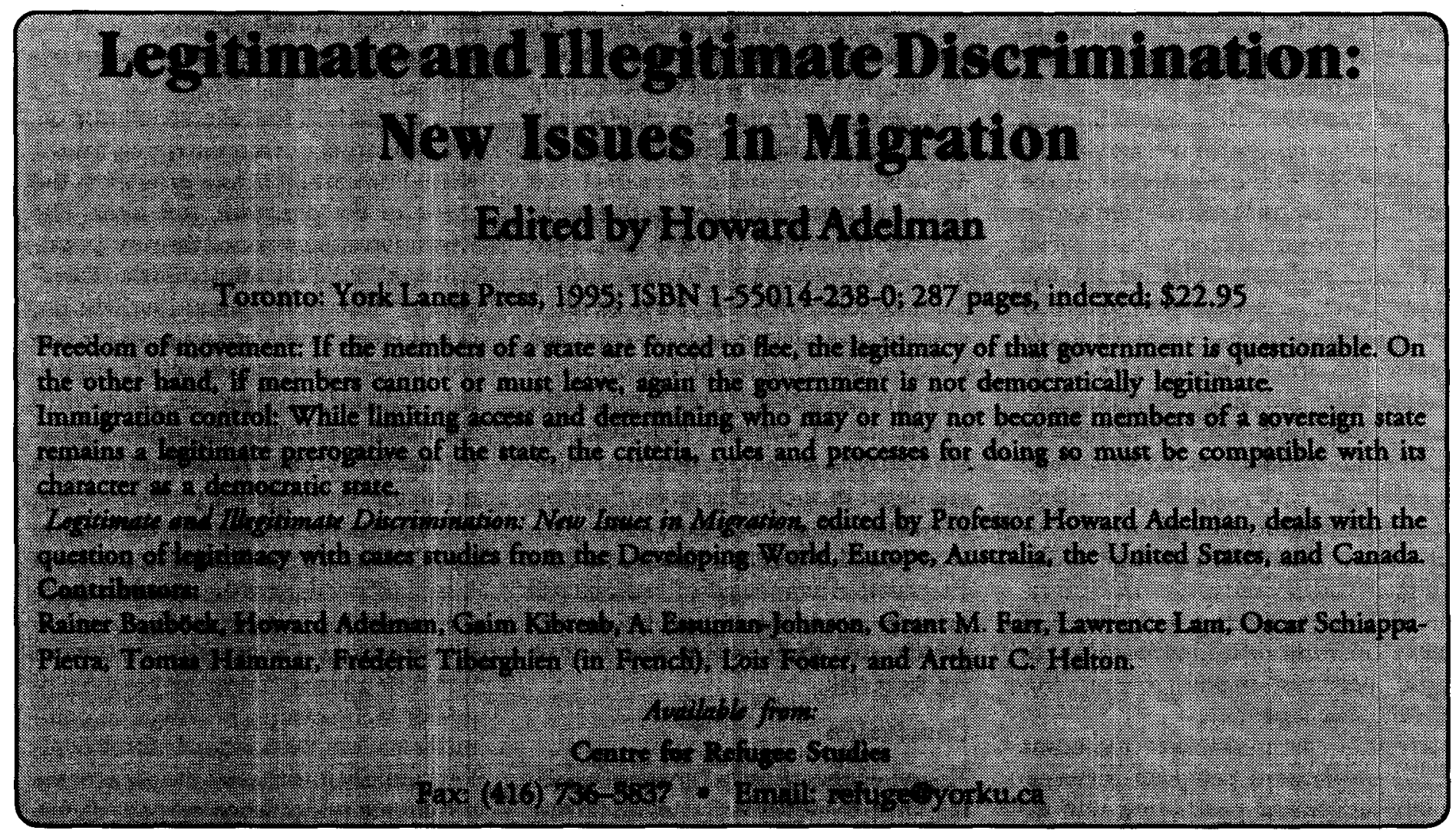

